\title{
Research and Development (R \& D) Sebagai Pilar Utama dalam Membangun Ekonomi Industri Pertahanan Indonesia
}

\author{
Endro Tri Susdarwono ${ }^{1^{*}}$ \\ ${ }^{1}$ Program Studi Ilmu Komunikasi, Universitas Peradaban Brebes, Indonesia \\ Email: ${ }^{1}$ saniscara99midas@gmail.com
}

\section{INFORMASI ARTIKEL}

\section{Data artikel:}

Naskah masuk, 30 Juni 2020

Direvisi, 19 Agustus 2020

Diterima, 24 Agustus 2020

\section{Kata Kunci:}

Dual-use technologies

Industry pertahanan

Research and development (R\&D)

\begin{abstract}
ABSTRAK
Abstract- This study intends to describe how defense research and development (R\&D), which is a major pillar, is used to accelerate efforts towards independence in the economy of the Indonesian defense industry. This research is qualitative research, the type of research uses a comprehensive analytical study and analytical normative approach. At present, almost all countries that provide large-scale military equipment are supported by strong research capacity and domestic technological capacity. Therefore, efforts to develop highly competitive defense technology with established R\&D support are essential. Not only to face security threats but also make Indonesia relevant in the fierce competition in the era of economic globalization ahead. The country can reap optimum benefits from its defense industry $R \& D$ activities. In addition to strengthening war machines and arsenal, most of the research and development activities also encourage the use of research results for commercial or non-military industrial activities. The pattern of a symbiosis of military technology mutualism for use in the general public (commercial) has recently become a reference for policy developers known as the concept of dual-use technologies. The concept of dual-use technologies is then applied in the form of tiered trees that describe the roots of $\mathrm{R} \& \mathrm{D}$ for a product or technology in general that must be developed and then grow like branches and branches to specific specifications for military or commercial use.
\end{abstract}

Abstrak- Penelitian ini bermaksud mendeskripsikan bagaimana research and development (R\&D) pertahanan yang merupakan suatu pilar utama digunakan untuk melakukan akselerasi dalam usaha menuju kemandirian dalam ekonomi industry pertahananan Indonesia. Penelitian ini merupakan penelitian kualitatif, tipe penelitiannya menggunakan kajian komprehensif analitis dan pendekatannya normatif analitis. Saat ini, hampir semua negara penyedia peralatan militer berskala besar ditopang oleh kemampuan riset dan pembedayaan kapasitas teknologi yang kuat dari dalam negeri. Karena itu, upaya pengembangan teknologi pertahanan berdaya saing tinggi dengan dukungan $R \& D$ yang mapan sangat penting. Bukan saja untuk menghadapi ancaman keamanan, tapi juga membuat Indonesia relevan dalam persaingan sengit di era globalisasi ekonomi di depan. Negara dapat memetik 
manfaat optimal dari kegiatan $R \& D$ industry pertahanannya. Selain untuk memperkuat mesin-mesin perang dan arsenal, sebagian besar kegiatan penelitian dan pengembangan ini juga mendorong penggunaan hasil riset tersebut untuk kegiatan komersial atau industry nonmiliter. Pola symbiosis mutualisme teknologi militer untuk penggunaan di masyarakat umum (komersial) belakangan menjadi acuan para pengembang kebijakan yang dikenal dengan konsep dual-use technologies. Konsep dual-use technologies kemudian diaplikasikan dalam bentuk pohon berjenjang yang menggambarkan akar dari R\&D untuk sebuah produk atau teknologi secara umum yang harus dikembangkan, dan lantas tumbuh ibarat cabang dan ranting ke spesifikasi khusus untuk penggunaan militer atau komersial.

\section{Korespondensi:}

\section{Endro Tri Susdarwono}

Program Studi Ilmu Komunikasi, Universitas Peradaban Brebes

J1. Raya Pagojengan KM. 3 Paguyangan, Brebes, Indonesia

\section{PENDAHULUAN}

Riset dan pengembangan teknologi adalah hal yang mendasar dalam pembangunan dan upaya mencapai kemandirian industry pertahanan. Perang sejatinya dalah usaha untuk mengeksploitasi keunggulan disbanding musuh. Salah satunya lewat keunggulan teknologi. Karena itu, upaya R\&D yang intensif adalah syarat penting untuk memastikan keunggulan teknologi pertahanan. Pertahanan pun menjadi sector yang sangat technology-intensive.

Saat ini, hampir semua negara penyedia peralatan militer berskala besar ditopang oleh kemampuan riset dan pembedayaan kapasitas teknologi yang kuat dari dalam negeri (Haripin, 2011). Perang Dingin, sebagai contoh, memaksa Amerika Serikat, Rusia, serta negara-negara anggota NATO dan Pakta Warsawa mendedikasikan banyak sumber dayanya untuk aktivitas riset dan pengembangan atau research and development (R\&D) serta mengembangkan industry pertahanan secara massif. Tiongkok melakukan langkah serupa setelah hubungannya dengan Rusia memburuk. Adapun Taiwan mengembangkan kemampuan industry pertahanannya karena secara konstan terancam oleh potensi invasi Tiongkok. Hal yang sama dialami Korea Utara. Sedangkan Korea Utara dan Afrika Selatan dipaksa membangun kekuatan bersenjatanya sendiri sendiri akibat embargo senjata oleh komunitas internasional (Bitzinger (ed.), 2009).

Kegagalan pasar dalam $\mathrm{R} \& \mathrm{D}$. perusahaan swasta biasanya kurang banyak melakukan $\mathrm{R} \& \mathrm{D}$, sehingga ada kebutuhan untuk intervensi pemerintah guna memperbaiki kegagalan pasar ini (Yusgiantoro, 2014). Karena pertahanan adalah sector yang sangat technologyintensive, peran pemerintah untuk membantu aktivitas dan pendanaan $R \& D$ buat pengembangan tteknologi yang aplikatif untuk pertahanan sangat besar dampaknya. Wajar saja, karena perang sejatinya adalah usaha untuk mengeksploitasi keunggulan dibanding musuh. Salah satunya adalah keunggulan teknologi. Karena itu, upaya R\&D yang intensif adalah syarat penting untuk memastikan keunggulan teknologi pertahanan (Karim, 2014).

Posisi Indonesia dalam soal pendanaan R\&D lebih mirip Inggris. Pemerintah sebenarnya menyadari bahwa pengembangan industry pertahanan membutuhkan aktivitas penelitiian dan perekayasaan. Meski pemerintah membuka kemungkinan pendanaan 
dari APBN dan sumber pendanaan lain, pendanaan untuk aktivitas ini lebih diserahkan ke Industri pertahanan, sesuai dengan UndangUndang Nomor 16 Tahun 2012. Industry pertahnn diminta menydiakan paling rendah 5\% persen dari laba bersih untuk kepentingan penelitian dan pengembangan (Pasal 43 Undang-Undang Nomor 16 Tahun 2012 tentang Industri Pertahanan).

Dalam pasar komersial, produk didasarkan pada kualitas atau teknologi yang terbukti dan/atau merek yang mudah diidentifikasi yang menarik bagi konsumen. Hambatan untuk masuk ke pasar (entry barrier) di kebanyakan jenis industry juga tidak besar. Dalam pasar pertahanan, teknologinya harus canggih (cutting edge), lahir dari hasil riset dan pengembangan (R\&D) yang lama, ada barrier to entry yang besar dari sisi modal, regulasi, reputasi, teknologi dan paten. Risiko dan keuntungan dalam pasar komersial bervariasi, bergantung pada kinerja perusahaan dan persaingan. Tapi, di industry pertahanan, risiko dan laba sangat bergantung pada kebijakan pemerintah yakni kebijakan anggaran, kebijakan pengadaan, kebijakan kemandirian, ekspor-impor, dan lainnya (Scherer, 1964).

Kesiapan lainnya berupa penguasaan teknologi melalui penelitian dan pengembangan $(R \& D)$ di bidang pertahanan, guna mendorong perkembangan teknologi dan meningkatkan produktivitas SDM. Pelaksanaan R\&D harus bersinergi dengan perguruan tinggi dalam negeri maupun luar negeri agar dapat mengikuti inovasi yang sesuai dengan perkembangan zaman. Sinergitas juga diperlukan antar institusi yang terkait, guna meningkatkan interaksi riset (pertukaran pengetahuan dan pengalaman) agar hasilnya semakin berkualitas dan meminimalisir ketidakpastian (uncertainty) (Sebastian, 2015).

Karena itu, upaya pengembangan teknologi pertahanan berdaya saing tinggi dengan dukungan $R \& D$ yang mapan sangat penting. Bukan saja untuk menghadapi ancaman keamanan, tapi juga membuat Indonesia relevan dalam persaingan sengit di era globalisasi ekonomi di depan. Caranya dengan membangun ketangguhan daya saing lewat basis industri manufaktur berteknologi tinggi. Strateginya sudah jelas, yaitu mengoptimalkan nilai tambah dari industri pertahanan. Untuk itu, langkah awal yang harus dilakukan adalah mendorong substitusi impor untuk industri pertahanan dan mengupayakan komersialisasi (spin off) dari efek lanjutan (spillover effect) atau efek pengganda (multiplier effect) industri pertahanan, berupa produk yang bisa digunakan untuk kepentingan sipil (Indrawan dan Widiyanto, 2016).

Penelitian ini bermaksud mendeskripsikan bagaimana research and development (R\&D) pertahanan yang merupakan suatu pilar utama digunakan untuk melakukan akselerasi dalam usaha menuju kemandirian dalam ekonomi industry pertahananan Indonesia.

\section{METODE PELAKSANAAN}

Metode ialah cara kerja untuk dapat memahami sesuatu objek. Metode penelitian ialah cara kerja untuk memahami objek penelitian (kumpulan metode disebut metodik, sedangkan ilmu yang mempelajari metode disebut metodologi). Membahas metodologi akan mengungkap juga teknik - teknik: pengumpulan data atau cara memperoleh data, cara menentukan sampel, analisa data, variabel dan sub variabel yang terlibat, atau rumusrumus statistik yang digunakan. Tiap jenis penelitian akan menggunakan metode dan teknik pengumpulan data yang serasi dengan jenis penelitian. Sedangkan teknik diartikan sebagai alat kerja yang merupakan kelengkapan cara memperoleh data atau informasi.

Metode ilmiah yang digunakan untuk penelitian dinamakan metodologi penelitian. Metode ialah cara kerja untuk dapat memahami objek penelitian. Di samping metode dikenal pula teknik penelitian, teknik diartikan sebagai alat kerja yang merupakan kelengkapan cara kerja (metode). Sebenarnya 
teknik tercakup di dalam metode, yang bila dipandang dari segi pelaksanaannya. Metode sebagai alat kerja lebih ditekankan kepada cara kerja pikiran dalam rangka memahami objek penelitian. Teknik dipandang sebagai cara kerja untuk melakukan atau menangkap hasil cara kerja pikiran.

\section{a. Metode Pendekatan}

Berbeda dengan pendekatan positivistik, metode kualitatif mengadopsi apa yang disebut sebagai pandangan ontologis-pengakuan bahwa realitas tidak objektif. Jika dikaitkan dengan komentar Devine yang telah disebut bahwa periset perlu masuk dalam setting sosial dari fokus riset-kita bisa memulai memahami bahwa konteks adalah aspek utama di balik riset kualitatiaf: apa yang sebenarnya kita cari jawabannya adalah bukan hanya "apa yang terjadi", tetapi juga "mengapa" dan "bagaimana." (Harrison, 2007).

Tipe penelitian ini mengunakan tipe kualitatif, dalam penelitian kualitatif yang terpenting adalah bagaimana menentuakan informan kunci yang sarat akan informasi sesuai dengan fokus penelitian. Metode kualitatif dapat digunakan untuk mengungkap dan memahami sesuatu dibalik fenomena yang sedikitpun belum diketahui. Metode ini dapat juga digunakan untuk mendapatkan wawsan tetang sesuatu yang harus sedikit diketahui, serta dapat membantu peneliti memberi rincian kompleks tentang fenomena yang sulit diungkapkan oleh metode kuantitatif. Format deskriptif kualitatif bertujuan untuk menggambarkan, meringkaskan berbagai kondisi, situasi atau berbagai fenomena realitas sosial yang ada di masyarakat yang menjadi objek penelitian dan berupaya menarik realitas itu ke permukaan sebagai suatu ciri karakter, sifat, model, tanda atau gambaran tentang kondisi, situasi, ataupun fenomena tertentu.

\section{b. Spesifikasi Penelitian}

Soerjono Soekanto melihat dari segi "sifat penelitian", beliau membedakannya menjadi 3 (tiga) tipe, yaitu penelitian eksploratori, penelitian deskriptif, dan penelitian eksplanatori. Sedangkan dilihat dari segi "tujuan penelitian", J. Vredenbregt membedakan penelitian sosial menjadi 3 (tiga) tipe, yaitu penelitian eksploratori, penelitian deskriptif, dan penelitian eksplanatori (Muhammad, 2004). Spesifikasi penelitian dalam penelitian ini menggunakan deskriptif kualitatif.

\section{c. Metode Pengumpulan Data}

Pengumpulan data merupakan prosedur yang sistematis untuk mengumpulkan data yang diperlukan dalam suatu penelitian. Selalu ada hubungan antara metode pengumpulan data dengan masalah yang diteliti. Untuk pengambilan data tersebut, diperlukan suatu alat pengumpul data, yang biasa disebut instrumen (pengumpul data) atau alat pengumpulan. Jenis metode pengumpulan, yaitu:

1) Studi Pustaka (bibliography study);

Pengumpulan data dilakukan dengan studi pustaka meliputi sumber yang relevan dengan permasalahan; catatan transkrip, buku, surat kabar, majalah, agenda, arsip, dan pustaka lainnya. Studi pustaka dilakukan melalui tahap-tahap identifikasi pustaka sumber data, identifikasi bahan yang diperlukan, dan inventarisasi bahan (data) yang diperlukan tersebut. Data yang sudah terkumpul kemudian diolah melalui tahap pemeriksaan (editing), penandaan (coding), penyusunan (reconstructing), sistematisasi berdasarkan pokok bahasan dan subpokok bahasan yang diidentifikasi dari rumusan masalah (systematizing).

2) Dokumen (document study)

Dokumentasi dilakukan untuk mendapatkan data dengan memanfaatkan data sekunder yang sudah tersedia atau terolah. Data sekunder ini antara lain berupa dokumen-dokumen resmi organisasi pemerintah maupun dokumen institusi lain.

\section{d. Teknis Analisis}

Analisis data (analyzing), yaitu menguraikan data dalam bentuk kalimat yang baik dan benar, sehingga mudah dibaca dan diberi arti (diinterpretasikan) sehingga hasil analisis data memudahkan pengambilan kesimpulan secara induktif.

Anallisis data adalah merupakan suatu teknik untuk menganalisa berbagai macam data yang ditemukan dan diperoleh peneliti dilapangan, data tersebut baik itu diperoleh dari, hasil observasi atau pengamatan langsung kepada objek yang diteliti ataupun didapat dari studi dokumen-dokumen yang ditemukan. Kemudian data-data yang didapat tadi 
dihubungkan dan dikaitkan dengan pokokpokok permasalahan yang ada.

Menurut Miles dan Huberman analisa data adalah merupakan suatu kegiatan yang mengacu pada penelahaan atau pengujian yang sistematik mengenai suatu hal dalam rangka menentukan bagian-bagian, hubungan di antara bagian dan hubungan dalam keseluruhan. Kegiatan ini dilakukan secara bersamaan dan saling menjalin diantara reduksi data dan penarikan kesimpulan atau verifikasi, dimulai dari pengumpulan data dan kembali memberi umpan balik pada pengumpulan data. Ada tiga unsur utama dalam proses analisis data pada penelitian kualitatif, yaitu:

1) Reduksi data

Reduksi data adalah merupakan bagian dari proses analisis yaitu bentuk analisis untuk mempertegas, memperpendek, membuat fokus, membuang hal yang tidak penting dan mengatur data, sehingga dapat dibuat kesimpulan. Proses reduksi data ini berlangsung terus menerus sepanjang pelaksanaan penelitian, berupa singkatan, pembuatan kode, memusatkan tema, membuat batas-batas persoalan dan menulis memo.

2) Sajian data

Sajian data adalah merupakan suatu susunan informasi yang memungkinkan dapat ditariknya suatu kesimpulan penelitian. Dengan melihat sajian data ini maka peneliti akan memahami apa yang terjadi serta memberikan peluang bagi peneliti untuk mengerjakan sesuatu pada analis atau tindakan lain berdasarkan pemahamannya. Penyajian data dalam bentuk matriks gambar, skema, jaringan, kerja dan tabel mungkin akan banyak membantu menganalisis guna mendapatkan gambaran yang jelas serta memudahkan dalam menyusun kesimpulan penelitian. Pada dasarnya sajian data dirancang untuk menggambarkan suatu informasi secara sistematik dan mudah dilihat serta dipahami dalam bentuk keseluruhan sajiannnya.

3) Penarikan Kesimpulan

Sejak awal pengumpulan data peneliti harus sudah mulai memahami makna dari hal-hal yang ditemui dengan mencatat keteraturan, pola-pola, pernyataan dari berbagai konfigurasi yang mungkin, arah hubungan kausal dan proposisi. Kesimpulan akhir pada penelitian kualitatif tidak akan ditarik kecuali, setelah proses pengumpulan data berakhir. Kesimpulan yang dibuat perlu diverifikasi dengan cara melihat dan mempertanyakan kembali, sambil meninjau secara sepintas pada catatan lapangan untuk memperoleh pemahaman yang lebih tepat.

Dalam penelitian ini penulis menggunakan teknik analisis data dengan model strategi analisis deskriptif kualitatif. Model teknik analiisis ini dapat memberikan gambaran bagaimana alur logika analisis data pada penelitian kualitatif sekaligus dapat memberikan masukan terhadap bagaimana teknik analiis data kualitatif digunakan. Analisis ini tidak menutup diri terhadap penggunaan data kuantitatif, bahkan penggunaan data kuantitatif ini bermanfaat untuk pengembangan analisis data kualitatif itu sendiri.

\section{HASIL DAN PEMBAHASAN}

a. Research and Development (R\&D) Pertahanan di Negara Maju

Anggaran pertahanan setiap negara, umumnya dapat dikelompokkan ke dalam anggaran untuk membiayai penelitian, pengembangan, pengujian dan evaluasi atau Research, Development, Test and Evaluation (RDT\&E). belanja untuk RDT\&E menunjukkan pertumbuhan jangka Panjang yang konstan sejak 1940an. Selama periode 1948-2007, biaya total RDT\&E adalah sekitar $42 \%$ dari pengeluaran kumulatif Kemhan AS (Yusgiantoro, 2014).

Anggaran pertahanan AS meningkat dari 9,3\% (1952) menjadi 13,2\% (1960) dari PDB. Pada tahun 1960 pemerintah mendanai 58\% dari semua RDT\&E industry nasional. Pada waktu itu industry pertahanan di AS adalah sector industry terbesar, melebihi industry mobil, baha, atau minyak sekalipun. Industry pertahanan tumbuh menjadi sector yang unik dengan permintaan khusus. Data menunjukkan bahwa sejah tahun 1948 hingga beberapa tahun terakhir ini, investasi tahunan Kemhan AS untuk RDT\&E menunjukkan peningkatan 
jangka Panjang yang berkelanjutan. Anggaran pertahanan untuk pengadaan alutsita dan RDT\&E meningkat dari sekitar $22 \%$ pada tahun 1948 menjadi lebih dari 32\% pada tahun 1960, yang mencerminkan tingkat pertumbuhan investasi AS dalam teknologi, dan sistem tempur canggih. Belanja untuk RDT\&E tumbuh rata-rata lebih dari $18 \%$ per tahun, sementara untuk pengadaan alutsista hanya meningkat rata-rata $8,3 \%$. Pemerintah AS mengalokasikan dana untuk RDT\&E cukup besr, hal ini menunjukkan perhatian, dan pentingnya kegiatan ini dalam mendukung pembangunan industry pertahanannya.

Dengan membandingkan biaya yang dikeluarkan untuk kegiatan RDT\&E di negaranegara maju, terutama yang unggul dalam pembangunan kekuatan pertahanan, yaitu AS, Jerman, Perancis, Inggris, Italia, Jepang, dan Kanada, setelah Perang Dingin (1991), AS masih mengalokasikan biaya untuk RDT\&E untuk sector pertahanan sangat besar. Hal ini menunjukkan di AS, prinsip dasar pembangunan kekuatan pertahanan adalah (a) perlu didukung oleh industry pertahanan yang kuat, dan (b) perlu mempunyai landasan yang solid dan kokoh dari kegiatan intensif untuk RDT\&E (Yusgiantoro, 2014).

Kebutuhan anggaran untuk membangun kekuatan militer yang Tangguh melalui peningkatan anggaran pertahanan untuk membiayai Perang Dingin dan Perang Korea, menyebabkan perkembangan pesat industry pertahanan. Tahun-tahun awal perkembangan industry pertahanan ditandai dengan perubahan dan ekspansi yang dinamis, termasuk banyak perusahaan yang masuk dan keluar. Hambatan untuk masuk relative lebih rendah dibandingkan dengan industry lain karena tuntutan kebutuhan penyediaan teknologi dengan standar tertentu. Perusahaan yang memutuskan untuk masuk dan keluar dari bisnis pertahanan sering melakukannya secara sukarela (Yusgiantoro, 2014).

Sebagai perbandingan, India (http://www.clidefence.com/defenceindustry.as pid=1) yang merupakan sebagai salah satu negara berkembangn yang banyak menghadapi konflik besar dengan negara tetangganya, sejak awal kemerdekaan sudah berupaya mempunyai industry pertahanan sendiri. Namun, ketergantungan India terhadap peralatan pertahanan negara lain cukup lama. Keinginan untuk mencapai kemandirian terkendala oleh teknologi dan anggaran. Pada mulanya, India menganut strategi industrialisasi oleh negara (state led industrialization). Produksi peraltan pertahanan dilakukan oleh pemerintah sejak awal sesuai resolusi Kebijakan Industri tahun 1948. Undang-Undang India tentang Pengembangan dan Pengaturan Industri (1951), menetapkan prinsip-prinsip dasar kebijakan industry. Dalam kebijakan ini, industry pertahanan yang memerlukan investasi besar dan dukungan RDT\&E yang kuat dikendalikan pemerintah dengan sistem lisensi. Kebijakan itu, terwujud dengan terbangunnay infrastruktur produksi, antara lain berupa puluha pabrik artileri dan puluha laboratorium RDT\&E. namun, tidak hanya perusahaan pemerintah yang terlibat dalam produksi peralatan pertahanan. Sector swasta juga ikut terlibat dengan bertindak sebagai subkontraktor dan industry pendukung, seperti dalam pengadaan bahan mentah, produk antara, suku cadang dan komponen untuk pabrik-pabrik artileri dan juga bengkel-bengkel indusri mili AD, AL, dan AU. Sekitar 20-25\% produk industry pertahanan pemerintah diproduksi oleh perusahaan swasta, besar, dan kecil. Dampaknya beberapa peralatan pertahanan yang canggih dapat dibuat oleh perusahaan swasta. Untuk mencapai tujuan kemandirian dalam sector pertahanan, pemerintah India mengutamakan industry pertahanan dalam negeri, kecuali ika teknologinya tidak memungkinkan atau secara ekonomi tidak layak. Lain hanya dengan kegiatan industry pertahanan Pakistan (http://www.defence.pk/pakistan-defence-

industry/) yang dimulai tahun 1951 dengan pendirian Pabrik Artileri Pakistan atau Pakista Ordonance Factory (POF). POF merupakan cikal bakal industry pertahanan Pakistan Industri pertahanan Pakistan terus dikembangkan dengan prioritas lebih besar daripada pembangunan ekonominya. Hal ini, disadari oleh Pakistan sebagai negara yang selalu mendapatkan ancaman dari lingkugnannya, sehingga pembangunan kekuatan militer merupakan prioritas utama yang dilakukan secara berkelanjutan (Yusgiantoro, 2014).

Pada awal industry pertahanan berkembang pesat di Eropa Barat (Inggris, Perancis, dan Jerman), sejak PD I, PD II, 
Perang Korea dan Perang Dingin, telah terjadi pergeseran pertumbuhan industry pertahanan AS. Salah satu keberhasilan industry pertahanan AS, karena banyak memberikan perhatian pada kegiatan penelitian dan pengembangan alutsista. Menjelang akhir tahun 1960-an, anggaran kegiatan RDT\&E digunakan untuk litbang pesawat tempur sekitar 19\% dari nilai penjualan, jauh lebih tinggi dari industry keseluruhan yang kuran gdari 3\%. Kegiatan litbang untuk militer lebih unggul dibandingkan sector komersial, terutama dalam penerapan inovasi teknologi. Kegiatan RDT\&E teknologi pertahanan terfokus pada perangkat keras dan sistem baru, sebaliknya untuk mayoritas perusahaanperusahaan komersial hanya untuk perbaikan produk yang sudah ada. Dengan demikian, kebutuhan akan keterampilan teknik bagi industry pertahanan AS sangat tinggi. Keterampilan individu dan kelompok sangat diperlukan untuk mengembangkan sistem pertahanan baru. Untuk itu, diperlukan waktu dan upaya yang berkelanjutan (Yusgiantoro, 2014).

Sector swasta dinilai mempunyai kemampuan yang lebih baik dalam iptek, manajemen, dan modal. Keterlibatan sector swasta dengan iptek kelas dunia, tidak hanya akan meningkatkan kapabilitas porduksi pertahanan India, tetapi juga akan memperluas lapangan kerja dan memperbanyak infrastruktur, dan akhirnya mendorong pertumbuhan ekonomi. Kebijakan membuka partisipasi sector swasta dalam produksi pertahann disambut baik oleh industry dalam negeri dan investor asing. Banyak industry besar menunjukkan keinginan untuk berinvestasi dalam RDT\&E dan infrastruktur untuk pembangunan kapabilitas produksi pertahanan. Kebijakan ini menyebabkan sector swata India mampu membuat berbagai jenis peralatan pertahanan, tidak lagi hanya sebagai pemasok bahan mentah, komponen, pembuat subsistem saja, melainkan uuga menjadi mitra kerja sma dalam pembuatan sistem atau peralatan canggih secara penuh.

Dalam artikel yang ditulis oleh Dr. Derek Braddon bertajuk "Commercial Applications of Military R\&D: US and Eu Program $s$ Compared", bisa kita pelajari bahwa di era Perang Dingin, misalnya, belanja R\&D negaranegara untuk industry pertahanan membukukan rekor sampai US\$120 miliar. Dari total besaran dana ini, 35 persen di antaranya merupakan belanja $R \& D$ militer Amerika Serikat.

Lantas bagaimana negara-negara tersebut dapat memetic manfaat optimal dari kegiatan R\&D industry pertahanannya? Rupanya, selain untuk memperkuat mesin-mesin perang dan arsenalnya, sebagian besar kegiatan penelitian dan pengembangan ini juga mendorong penggunaan hasil riset tersebut untuk kegiatan komersial atau industry nonmiliter. Braddon mencatat bertapa negara-negara yang terlibat Perang Dingin memperoleh berkah dari riset industry pertahanannya. Di antaranya yang cukup mengemuka mencakup penggunaan radar, mesin jet, hingga sistem navigasi pesawat komersila. Untuk Amerika Serikat, misalnya, belanja riset yang dianggarkan oleh Badan Antariksa, NASA, kerap mempengaruhi kecenderungan pengembangan teknologi penerbangan sipil. Sebaliknya, di seberang Atlantik, negara eropa seperti Inggris, Prancis, dan Italia juga terlihat mengikuti pola yang sama dengan "sekutu" mereka, Amerika Serikat.

Pola symbiosis mutualisme teknologi militer untuk penggunaan di masyarakat umum (komersial) belakangan menjadi acuan para pengembang kebijakan yang dikenal dengan konsep dual-use technologies. Selain contoh menarik antara Boeing dan Lockheed Martin daalam kasus pengembangan Boeing dari teknologi desain pesawat angkut militer, kita bisa melihat penggunaan peranti militer di pengembangan aluminium dan lithium untuk peranti komersial.

Melihat kecenderungan ini, tak salah jika di beberapa negara maju, konsep dual-use technologies kemudian diaplikasikan dalam bentuk pohon berjenjang yang menggambarkan akar dari R\&D untuk sebuah produk atau teknologi secara umum yang harus dikembangkan, dan lantas tumbuh ibarat cabang dan ranting ke spesifikasi khusus untuk penggunaan militer atau komersial.

Yang menarik, ternyata, di sector teknologi informasi (IT), tren yang terjadi terkait dengan maraknya penggunaan IT di masyarakat sipil malah yang menjadi faktro yang turut memicu pengembangan IT unutk kepentingan militer hingga intelijen. Tengok saja di era maraknya media social seperti 
Facebook, Twitter, Plurk, hingga situs-situs dan blog antarkomuniatas jika merujuk pada keterangn mantan karyawan bagian IT Lembaga pertahanan Amerika Serikat, Edward Snowden, untuk mendorong Dewan Pertahanan Nasional (NSA) mengembangkan teknologi pemantauan atau mata-mata.

Keterkaitan era tantara R\&D industry pertahanan dan kepentingan nonmiliter sebenarnya elah menjadi titik perhatian utama negara-negara maju setelah Perang Dunia II. Debat yang muncul, merujuk pada paper dari Giulio Perani, "Military Technologies and Commercial Applications: Public Policies in NATO Countries (Perani, 1997), memicu maraknya polemic konversi teknologi militer ke sipil atau konsep dual-use. Perbedaan terminology ini merujuk pada superioritas teknologi yang muncul dan proses "integrase teknologi" militer ke sipil, atau sebaliknya. Di Amerika Serikat umumnya lebih ada tren integrase R\&Dmiliter ke sipil di awal-awal maraknya konsep dual-use technologies. Di Inggris, Perani menemukan data, pada awal 1990-an, tidak kurang dari 55 ersen total biaara R\&D militer ternyata penggunaannya lebih banyak oleh industry nonmiiter. Efek berantainya bahkan terasa hingga pada konsep kepemilikan dan pengembangan investasi. Para pembayar pajak mendesak agar ada alternative pembiayaan riset hingga permodalan industry pertahanan di Inggris.

AS adalah contoh nyata negara yang power-nya terletak pada keunggulan $R \& D$ untuk militer. Bahkan seluruh strategi pertahanan, kebijakan luar negeri, dan prinsip keamanan nasional AS dibangun atas basis ideologi untuk mempertahankan superioritas teknlogi yang substansial terhadap negara musuh dan sekutu. Paradigma ini lahir semasa Perang Dingin. Karena jumlah tantara AS jauh lebih sedikit disbanding Uni Soviet, AS mengimbanginya dengan berusaha unggul dari sisi teknologi. Kebijakan ini tetap dianut sampai sekarang (Gansler, 2012).

Tiongkok, yang dipandang sebagai rival geopolitik dan geoekonomi AS, sebenarnya taka da apa-apanya. Betul, tiongko memiliki 2,28 juta orang tantara regular, sementara AS hanya memiliki 1,56 juta tantara pada 2010 . Masalanya, belanja militer AS mencapai US\$712,8 miliar, sementara anggaran pertahanan Tiongkok hanya US\$98,36 miliar atau 13,7 persen dari anggaran AS. Jumlah orang boleh kalah, tapi AS jauh lebih unggul dari aspek persenjataan dan teknologi (International Institute for Strategic Studies, 2011).

Skala investasi AS untuk kepentingan R\&D juga mencengangkan, yakni mencapai US\$70 miliar per tahun. Karna ideologi AS adalah memerptahankan keunggulan teknologi di atas semua negara. AS memainkan peran proaktif dan dominan dengan semua pendanaan aktivitas $R \& D$ pertahanan bersumber dari pemerintahnya. Sekitar 70 persen pendanaan disalurkan ke industry pertahanan. Sedangkan 25 persen lainnya dikerjakan oleh laboratorium yang didanai pemerintah. Adapun 5 persen sisanya dilakukan perguruan tinggi.

Pemerintah AS menyadari aspek menyulitkan dari pendanaan R\&D. sulit bagi industry untuk menyisishkan dana perusahaan yang terbatas buat aktivitas R\&D yang mahal, berkarakter high-tech dan high risk, dengan harapan, suatu saat, pemerintah AS akan membeli produknya. Risikonya jelas terlalu besar buat perusahaan manapun. Maka pemerintah AS memutuskan mndanai aktivitas $\mathrm{R} \& \mathrm{D}$ karena market rationale tak mungkin industry melakukan $R \& D$ dengan volume, nilai, kedalaman, dan cakupan yang diinginkan untuk mempertahankan ideologi keunggulan teknologi.

Manfaat dari pendanaan yang massif untuk R\&D ini diraskaan sector komersial berupa efek tumpah (spillover effect) dan spinoff produk komersial hasil turunan produk militer. Computer yang kita kenal sekarang, contohnya, sebenarnya berasal dari proyek Electronic Numerical Integrator and Computer (ENIAC) yang dirintis AS sejak 1945. Proyek virtual network yang dikembangkan DARPA pada 1974 menjadi dasr bagi pengembangan internet yang kita nikmati sekarang. Produk lain seperti Global Positioning System (GPS), semikonduktor, mesin jet, pendingin, reactor nuklir, container kapal, satelit cuaca, dan sistem navigasi sesungguhnya lahir dari $R \& D$ untuk kepentingan militer (Bitzinger (ed.), 2012).

Ini berbeda dengan kebijakan Inggris. Pemerintah Inggris tidak menyediakan pendanaan untuk aktivitas riset. Pemerintah Inggris malah mengharapkan industry 
menyisihkan pendanaan untuk ini. Hanya ada satu pembeli bagi industry pertahanan Inggris, yakni pemerintah negara itu sendiri. Jika customer ini tidak berminat mensponsori suatu produk, prospek untuk ekspor tak akan pernah terjadi.

Buku putih Defense Technology Strategy 2006, yang disusun Kementerian Pertahanan Inggris, memerpjelas posisi itu. Meski mereka berpandangan bahwa Inggris sebaiknya mengalokasikan pendanaan R\&D untuk mendesain, mengembangkan, memproduksi, dan mendukung sistem strategis seperti senjata nuklir, kapal selam, dan complex weapon semacam peluru kendali serta cybercapabilities, sampai sejauh ini realisasi pendanaan R\&D terbatas hanya untuk pengembangan alpalhankam buat mendukung operasi di Irak dan Afganistan (Ministry of Defense Technology Strategy, 2006).

Pelajaran moral yang bisa dipetik dari pola pengembangan $R \& D$ industry pertahanan di Tanah Air, berbagai ulasan menunjukkan tren hingga dampak lanjutan dari perubahan komitmen negara seperti yang terjadi dengan lahirnya BAE Systems di Inggris. Di Indonesia dewasa ini, barangkali, seperti yang terjadi di INggris pada 1986, pernah muncul program LINK yang melibatkan sejumlah universitas, Lembaga riset terkemuka, perusahan komersial, hingga industry pertahanannya (Karim, 2014).

b. Research and Development (R\&D) Pertahanan di Indonesia sebagai Pilar Utama Kemandirian Industri Pertahanan

Menurut Peraturan Menteri Pertahanan Republik Indonesia Nomor 39 Tahun 2011 tentang penelitian dan pengembangan bidang pertahanan di lingkungan Kementerian Pertahanan dan Tentara Nasional Indonesia Pasal 1:

1) Ayat (1) Penelitian adalah kegiatan yang dilakukan menurut kaidah dan metode ilmiah secara sistematis untuk memperoleh informasi, data dan keterangan yang berkaitan dengan pemahaman dan pembuktian kebenaran atau ketidak benaran suatu asumsi dan/atau hipotesis di bidang ilmu pengetahuan dan teknologi serta menarik kesimpulan ilmiah bagi keperluan ilmu pengetahuan dan teknologi. Sesuai dengan pengertian di atas maka penelitian terdiri dari dua proses yaitu pembentukan hipotesa yang dirumuskan dari data, fakta dan teori yang telah ada sebelumnya, serta tahap kedua adalah proses verifikasi terhadap hipotesa untuk menarik kesimpulan. Proses pertama akan selalu mengembangkan teori-teori berdasarkan teori yang ada sebelumnya serta faktafakta yang terjadi di alam sehingga akan selalu mengembangkan ilmu pengetahuan secara terus-menerus. Pada proses yang kedua yaitu verifikasi sebenarnya merupakan proses penyaringan hipotesa, hipotesa yang benar dapat dikatakan menambah khasanah ilmu pengetahuan sedangkan hipotesa yang salah akan membersihkan ilmu pengetahuan dari kesalahan. Sesuai dengan tahapan proses penelitian maka dapat ditarik kesimpulan bahwa penelitian merupakan proses pengembangan ilmu pengetahuan dengan cara membersihkan ilmu pengetahuan dari kesalahan dan menambah khasanah ilmu pengetahuan dari hasil penelitian.

2) Ayat (2) Pengembangan adalah kegiatan ilmu pengetahuan dan teknologi yang bertujuan memanfaatkan kaidah dan teori ilmu pengetahuan yang telah terbukti kebenarannya untuk meningkatkan fungsi, manfaat dan aplikasi ilmu pengetahuan dan teknologi yang telah ada atau menghasilkan teknologi baru. Sesuai dengan pengertian pengembangan maka pengembangan harus mempunyai prasyarat yaitu adanya ilmu pengetahuan dan teknologi yang diperoleh lebih dahulu baru kemudian penerapannya pada pemanfaatan sesuai dengan tujuan tertentu. Pengembangan yang bertujuan memanfaatkan ilmu pengetahuan maka tujuannya lebih mengarah kepada pengguna (user). Kepentingan userharus ditampung dan diimplementasikan dalam pengembangan.

Perencanaan pengembangan harus selalu melibatkan user mulai dari tahap awal sehingga hasil pengembangan dapat digunakan oleh user.

3) Ayat (3) Penelitian dan Pengembangan yang selanjutnya disingkat Litbang adalah merupakan suatu daur kegiatan penelitian dan pengembangan, termasuk pengujian, penilaian serta pengkajian dalam bidang 
sistem dan metode, organisasi, insani, materiil dan doktrin yang masing-masing dapat berdiri, maupun sebagai suatu rangkaian bulat yang satu dengan yang lain tidak terpisahkan, hasil penelitian dan pengembangan dikembangkan serta diterapkan lebih lanjut ke arah pemanfaatan maupun peningkatan.

Proses Litbang yang meliputi kegiatan Litbang, pengujian dan penilaian serta evaluasi merupakan siklus yang berjalan terus-menerus. Pada tiap siklus sebenarnya menghasilkan suatu yang lebih baik karena telah mencakup evaluasi dari kesalahan-kesalahan yang terjadi. Proses Litbang ini secara ringkas dapat dikatakan sebagai proses pembentukan model, kemungkinan-kemungkinan terjadinya kesalahan dan cara menanggulanginya. Proses ini merupakan penyempurnaan terus-menerus yang dapat dijelaskan sebagai berikut:

1) Pemodelan merupakan satu perumusan tentang karakteristik yang akan mencakup variabel mana yang berpengaruh, pengaruhnya besar dan pengaruhnya yang kecil. Dari model ini dapat digambarkan perilakunya secara lengkap, pengaruhpengaruh yang besar pada model tersebut. Pengaruh variabel yang besar pada model dapat digunakan untuk mengendalikan perilaku model. Sebagai konsekuensi Litbang yang baik akan menemukan cara untuk mengendalikan proses dari modelnya sehingga dari model tersebut dapat dikembangkan pemanfaatannya dalam kehidupan manusia.

2) Kemungkinan terjadinya kesalahan sangat penting dalam proses Litbang karena dari sinilah sebenarnya kegagalan-kegagalan dapat terjadi. Untuk mengatasi kemungkinan kegagalan perlu dibuat diagram alir yang menggambarkan proses serta logikanya secara menyeluruh tentang kemungkinan terjadinya deviasi-deviasi yang mungkin menjadi sumber kegagalan yang dapat berakibat fatal. Diagram alir ini sering disebut Pohon kegagalan (Fall Tree). Proses ini yang meliputi kemungkinan terjadinya kegagalan dapat digunakan sebagai dasar untuk mengantisipasi dan menanggulangi kemungkinan-kemungkinan terjadinya kegagalan, sehingga proses Litbang menjadi lebih pasti atau lebih besar kemungkinan untuk berhasilnya.

3) Kegagalan biasanya terjadi pada variabelvariabel yang merupakan variabel pengendali yaitu variabel yang mempunyai pengaruh besar pada proses. Kemungkinan kegagalan dapat ditanggulangi dengan mengatur variabel pengendali sehingga proses dapat berlangsung sesuai dengan yang dikehendaki. Ketiga proses Litbang yaitu pemodelan, diagram pohon kegagalan dan cara mengatasinya dapat digunakan untuk menjamin keberhasilan dalam Litbang.

4) Ayat (11) Penelitian dan Pengembangan Bidang Pertahanan yang selanjutnya disingkat Litbanghan adalah perencanaan proposal Litbang di bidang pertahanan yang disusun secara berencana dan sistematis.

Litbang di Kementerian Pertahanan merupakan satu masalah yang rumit karena menyangkut Iptek yang multi disipliner, adanya keterbatasan penguasaan Iptek personel pelakunya, adanya keterbatasan anggaran untuk Litbang sehingga program Litbang yang dilaksanakan di Kemhan harus dapat dilaksanakan secara optimal. Kondisi ini menyebabkan bahwa program Litbang harus dilaksanakan secara berencana dan sistematis sehingga hasilnya dapat optimal dalam arti berguna untuk user, dibutuhkan oleh user, tidak terjadi tumpang tindih Litbang di Kemhan dan TNI, dan tidak terjadi kegagalan.

Situasi ini dipersulit dengan industri pertahanan domestik yang belum kompetitif karena masih rendahnya sumber daya manusia, kurangnya riset dan program pengembangan di bidang pertahanan (Tippe, 2013).

Bangsa Indonesia masih menghadapi kondisi lemahnya: 1) kapasitas dan kompetensi riset, 2) kemampuan pengembangan menuju proses penciptaan berbasis iptek; 3) jaringan kelemba-gaan dan peneliti di ranah lokal, regional, dan global; 4) produktivitas dan relevansilitbang nasional untuk menjawab kebutuhan teknologi masyarakat; dan 5) penda-yagunaan riset dan pengembangan nasional untuk penciptaan nilai tambah padasumberdaya alam dan produk inovasi nasional dalam rangka meningkatkan daya saing ekonomi.Kondisi tersebut sebagai implikasi dari rendahnya budaya dan literasi 
iptek bangsaIndonesia. Sehingga jamak ditemui beragam fenomena lanjutan seperti diskoneksi-tas hasil riset dengan kebutuhan dunia industri; diskoneksitas riset antara perguruan tinggi dengan lembaga-lembaga riset; dan di sisi lain belum optimalnya pengelo-laan dan pemanfaatan sumber daya riset (personil litbang seperti peneliti, perekayasa dan dosen; anggaran, dan fasilitas riset). Kondisi ini ditambah dengan belumadanya perencanaan sektor riset jangka panjang (Rencana Induk Riset Nasional 2010-2045, Ristekdikti, 2016).

Riset dan teknologi diakui berperan penting dalam mendorong perekonomian suatu negara. Berbagai teori pertumbuhan ekonomi dan fakta empiris telah membuktikan pentingnya peranan riset terhadap ekonomi. Model pertumbuhan ekonomi yang dikemukan oleh Cobb Douglas (Rudiger, Dornbush, Stanley Fisher, Richard Startz, 1998. Macroeconomics 7thedition. Boston: Irwin McGraw Hill) Solow dan Romer (Mankiw, N. Gregory, 2010. Macroeconomics 7th edition. New York: World Publisher) menunjukkan adanya peranan teknologi dalam mendorong pertumbuhan ekonomi suatu negara. Faktor teknologi dapat menciptakan efisiensi dalam penggunaan mo-dal dan tenaga kerja yang pada akhirnya mendorong pertumbuhan ekonomi. Bahkan model Romer yang menyatakan bahwa tingkat kemajuan teknologi bersifat endogen, yaitu bahwa perusahaan dapat mengontrol tingkat kemajuan teknologi me-lalui aktivitas riset dan pengembangan. Perusahaan yang memiliki komitmen dan kemampuan lebih besar dalam riset dan pengembangan, akan menikmati manfaat berupa kemajuan teknologi yang lebih cepat sehingga akan berimplikasi pada peningkatan efisiensi sehingga akan mendorong pertumbuhan. Fakta empiris menunjukkan bahwa negara-negara dengan pertumbuhan ekonomi yang tinggi didukung oleh besarnya kontribusi riset dan teknologi yang diperlihatkan oleh multifactor productivity (MFP).

Kebijakan dan anggaran pemerintah untuk riset dan pengembangan teknologi sangat dibutuhkan. Selama ini anggaran pemerintah kita untuk riset teknologi sangat minim bahkan lebih rendah daripada anggaran riset sebuah perusahaan asing. Investasi teknologi sangat menjanjikan untuk jangka waktu panjang dengan teknologi, pengelolaan kekayaan alam Indonesia bisa lebih optimal. Kekayaan alam yang dikandung di bumi Indonesia benar-benar akan dinikmati dan digunakan untuk kemakmuran rakyat (Wira, 2014).

Dalam teori tahapan tangga produksi atau ladder of production kemandirian industry pertahanan, industry pertahanan yang masih berada di fase awal memang hanya akan menjadi end-product assembler yang memproduksi sistem senjata dengan R\&D yang belum terlalu canggih, dengan mengandalkan lebih banyak komponen impor (Bitzinger (ed.), 2012).

Pemerintah sendiri menyadari bahwa peningkatan kemampuan dan penguasaan teknologi industry pertahanan harus dilakukan melalui aktivitas penelitian dan pengembangan (R\&D) serta perekayasaan. Aktivitas R\&D juga menjadi syarat mutlak menuju kemandirian pertahanan serta kemampuan merespons perkembangan teknologi pertahanan dan keamanan.

Undang-Undang Nomor 16 Tahun 2012 tentang Industri Pertahanan juga mengatur bahwa industry pertahanan diminta menyediakan paling rendah $5 \%$ dari laba bersih unuk kepentingan penelitian dan pengembangan di bidang pertahanan. Anggaran R\&D ini dapat dibebankan sebagai komponen biaya oleh industry pertahanan. Tapi ini bukan berarti beban utama untuk menggenjo9t aktivitas R\&D terletak di pundak industry pertahanan. Udang-Undang juga menegaskan, pelaksanaan R\&D serta perekayasaan dilakukan perguruan tinggi, institusi penelitian dan pengembangan, baik Lembaga pemerintah maupun swata nasional, TNI/Polri serta Lembaga negara lainnya sebagai pengguna, dan industry pertahanan sendiri. Untuk itu, diperlukan langkah menyinergikan aktivitas dan pendanaan untuk Lembaga lainnya (Pasal 28 Undang-Undang Nomor 16 Tahun 2012 tentang Industri Pertahanan).

Sebagai customer, kebijakan transparansi perencanaan dan keinginan pemerintah dalam pengadaan merupakan salah satu kunci penting keberhasilan dalam pembinaan dan sngat krusial bagi upaya pengembangan industrial pertahanan. Industry membutuhkan kepastian perencanaan pemerintah untuk menyiapkan 
fasilitas produksi, menghitung kapasitas, menyisihkan sejumlah sumber daya finansial, serta memfokuskan usaha pada aktivitas R\&D tertentu untuk menghasilkan produk yang sesuai dengan kebutuhan pemerintah (Heidenkamp et all., 2013). Tanpa kejelasan perencanaan pengadaan, industry tidak bisa menginvestasikan dananya untuk aktivitas $\mathrm{R} \& \mathrm{D}$ demi memproduksi produk-produk yang bisa dipastikan akan dibutuhkan oleh pemerintah.

Sudah dijelaskan sebelumnya, sebagai customer industry pertahnan, pemerintah harus transparan dalam perencanaan pengadaan alutsista. Transparansi pemerintah dalam perencanaan pengadaan alpalhankamnya dapat membantu proses konsolidasi industry pertahanan. Dengan perencanaan pembeiliah yang transparan dari pemerintah, industry pertahanan dapat mengusulkan produk yang sesuai, menghitung besar permintaan di masa depan, merampingkang organisasi, atau memfokuskan pendanaan untuk aktivitas riset dan pengembangan (R\&D) produk tertentu.

Meski manfaat prinsip kompetisi sudah dan sangat disadari, kontrak industry pertahanan sering berasal submer tunggal. Sector pertahanan menoleransi semacam praktek monopoli. Ini karena, dalam pasar pertahanan, teknologinya harus canggih (cutting edge), lahir dari hasil riset dan pengembangan $(R \& D)$ yang lama, ada barrier to entry yang besar dari sisi modal, regulasi, reputasi, teknologi, dan paten. Risiko dan keuntungan dalam pasar komersial bervariasi, bergantung pada kinerja perusahaan dan persaingan (Karim, 2014).

Ambil contoh, berbeda dengan AS, banyak pemerintah menyerahkan tanggung jawab pendanaan $R \& D$ kepada industry. Karena itu, langkah yang harus dilakukan adalah transparansi perencanaan pembelian pemerintah sebagai customer. Dengan transparansi, industry pertahanan dapat mengusulkan produk yang sesuai, menghitung besar permintaan di masa depan, dan memfokuskan pendanaan untuk aktivitas R\&D produk tertentu. Dengan transparansi, industry tak akan ragu menginvestasikan dananya untuk R\&D demi memproduksi produk-produk yang bisa dipastikn akan dibutuhkan oleh pemerintah dalam jangka waktu yang tidak terlalu lama (Karim, 2014).
Salah satu strategi pembinaan industry yang ditempuh pemerintah AS adalah integrase industry pertahanan, lewt merger, akuisisi, dan modl penggabungan lain. Harapannya, dengan inegrasi, modal perusahaan semakin kuat untuk menghindari risiko finansial berbisnis di sector pertahanan dan memiliki modal untuk riset (Karim, 2014).

Model penggabungan yang juga didorong pemerintah AS adalah membentuk konsorsium dalam proses tender. Meski biaya R\&D diongkosi pemerintah, dalam tender produk, utnuk membuat prototipe, industry sering harus merogoh kantong sendiri. Dengan tender terbatas dan biaya pembuatan prototipe yang tidak sedikit, jika kalah tender, sering perusahaan mengalami kerugian dan ujungnya terancam bangkrut.

Transparansi bisa menjadi kebijakan pertama yang perlu dilakkan pemerintah sebagai customer. Sejauhmana transparansi pemerintah dalam perencanaan pengadaan alat utama sitem snejata (alutsista) ikut menentukan sampai sejauh mana komitmen pemerintah sebagai pelanggan. Transparansi pemerintah dalam perencanaan pengadaan alpalhankannya dapat membantu proses konsolidasi industry pertahanan. Dengan prencanaan pembelian yang transparan dari pemerintah, industry pertahanan dapat mengusulkan produk yang sesuai, menghitung besar permintaan di masa depan, merampingkan organisasi, atau memfokuskan pendanaan untuk aktivitas riset dan pengembangan atau research and development (R\&D) produk tertentu (masalah pentingnya transparansi kebijakan pengadan dan contoh pengalaman beberapa negara maju diolah dari Heidenkamp et al., 2013).

Industry tak akan ragu menginvestasikan dananya untuk aktivitas R\&D demi memproduksi produk-produk yang bisa dipastikan akan dibutuhkan oleh pemerintah dalam jangka waktu yang tidak terlalu lama. Ini bisa mempercepat aspek pengiriman (delivery) yang diperlukan setelah pemesanan. Australia bisa menjadi contoh yang palin baik soal ini. Pemerintah Negeri Kanguru secara rutin merilis rencana shopping list dalam defense Capability Plan. Transparansi ini memang bertujuan memberikan gambaran soal arah dan besaran permintaan militer di masa depan. 


\section{KESIMPULAN}

Research and development (R\&D) pertahanan harus mampu meningkatkan kualitas alat utama sistem senjata (Alutsista) TNI. Di Indonesia pengembangan Alutsista TNI dilaksanakan dengan sinergi antara badan research and development $(\mathrm{R} \& \mathrm{D})$, pengguna dan industry sehingga akan terjadi kemandirian terhadap ekonomi industry pertahanan di Indonesia. Pengembangan Alutsista dilaksanakan dengan memanfaatkan teknologi dan industri yang telah dikuasai instansiinstansi lain di luar Kemhan dan TNI. Research and development (R\&D) atau Litbang pertahanan diarahkan untuk menghasilkan Alutsista yang dapat memenuhi konvensi senjata yaitu tidak boleh mengenai sasaran non combatan. Litbang pertahanan secara terus-menerus sesuai dengan siklus Litbang diarahkan untuk mampu memproduksi Alutsista dengan kuantitas dan kualitas yang tinggi.

\section{DAFTAR PUSTAKA}

Bahan Kuliah untuk mata kuliah Industri Pertahanan di Prodi Ekonomi Pertahanan Universitas Pertahanan, disampaikan 12 Maret 2014.

Bitzinger, Richard A. (ed.). (2009). The Modern defense Industry: Political, Eonomic, and Technological issues. Praeger Security International, California.

Braddon Dr. Derek. Commercial Applications of Military R\&D: US and EU Programs Comapred, University of the West of England, Bristol.

Sebastian, Elly. Peningkatan Peranan Sdm Pertahanan Nasionalguna Menghadapi Perang Generasi Keempat, Jurnal Pertahanan 05, No. 1.

Perani, Giulio. (1997). Military Technologies and Commercial Applications: Public Policies in NATO Countries", CeSPICentro Studi di Politica Internazionale Rome, Italia.

Harrison, Lisa. (2009). Metodologi Penelitian Politik. Terjemahan Tri Wibowo. Kencana, Jakarta.

Hartanto, Agus. (2013). Kajian Kebijakan Alutsista Pertahanan dan Keamanan
Republik Indonesia. LIPI Press, Jakarta.

Heidenkamp, Henrik John Louth, dan Trevor Taylor. (2013). The Defense Industrial Triptych: Government as Customer, Sponsor and Regulator, Essex: Royal United Services Institute for Defense and Security Studies.

http://www.clidefence.com/defenceindustry.as pid=1, diakses pada 12 Juni 2014.

http://www.defence.pk/pakistan-defenceindustry/, diakses pada 12 Juni 2014.

International Institute for Strategic Studies. (2011). The Military Balance 2011, Routledge, London.

Karim, Silmy. (2014). Membangun Kemandirian Industri Pertahanan Indonesia. Kepustakaan Populer Gramedia, Jakarta.

Mankiw, N. Gregory. (2010). Macroeconomics 7th edition. World Publisher, New York.

Ministry of Defense Technology Strategy, 2006). Bisa dilihat di http://www.science.mod.uk/modwww/ content/dts complete.pdf. Diakses pada 12 Mei 2020).

Muhamad Haripin,'Problematika Industri Pertahanan Indonesia," Website Pusat penelitian Politik LIPI, WwW.politik.lipi.go.id, 29 Juli 2011, diakses pada 12 Juni 2014.

Peraturan Menteri Pertahanan Republik Indonesia Nomor 39 Tahun 2011 tentang penelitian dan pengembangan bidang pertahanan di lingkungan Kementerian Pertahanan dan Tentara Nasional Indonesia

Peraturan Presiden Republik Indonesia Nomor 79 Tahun 2019

Indrawan, Raden Mas Jerry dan Widiyanto, Bayu. Kebijakan Offset dalam Membangun Kemandirian Pertahanan Negara, Jurnal Pertahanan 06, No. 2.

Rudiger, Dornbush, Stanley Fisher, Richard Startz. (1998). Macroeconomics 7thedition. Irwin McGraw Hill, Boston.

Scherer, Frederic M. (1964). The Weapons Acquisition Process: Economic Incentives. Cambridge, MA: Harvard University Press. 
Supriyatno, Makmur. (2014). Tentang Ilmu Pertahanan. Yayasan Pustaka Obor Indonesia, Jakarta.

Tippe, Syarifudin. (2013). Defense Offset Policy in Indonesia," Bisnis dan Birokrasi: Jurnal Ilmu Administrasi dan Organisasi 20, No. 2.

Undang-Undang Nomor 16 Tahun 2012 tentang Industri Pertahanan.

Wira Media Informasi Kementerian Pertahanan Volume 52 / No. 36 / Januari-Februari 2015.

Yusgiantoro, Purnomo. (2014). Ekonomi Pertahanan: Teori \& Praktik. PT Gramedia Pustaka Utama, Jakarta. 